NBER Working Paper Series

THE INDEPENDENT JUDICIARY IN AN

INTEREST-GROUP PERSPECTIVE

William M. Landes and Richard A. Posner

Working Paper No. 110

CENTER FOR ECONOMIC ANALYSIS OF HUMAN BEHAVIOR

AND SOCIAL INSTITUTIONS

National Bureau of Economic Research, Inc.

204 Junipero Serra Boulevard, Stanford, CA 94305

October 1975

Preliminary; not for quotation.

NBER working papers are distributed informally and in limited number for comments only. They should not be quoted without written permission of the author.

This report has not undergone the review accorded official NBER publications; in particular, it has not yet been submitted for approval by the Board of Directors.

The research reported herein was performed pursuant to a grant from the National Science Foundation to the NBER for research in the area of law and economics. The opinions expressed herein are those of the author and do not necessarily reflect the views of the National Science Foundation. 


\title{
THE INDEPENDENT JUDICIARY IN AN INTEREST-GROUP PERSPECTIVE*
}

\author{
William M. Landes and Richard A. Posner \\ The University of Chicago Law School \\ and \\ National Bureau of Economic Research
}

\section{Introduction}

Economists, even those who are deeply interested in government and politics, have not examined critically the idea of a nonpolitical, or "independent," judiciary. 1 Most economists would doubtless agree with Professor Buchanan that the judiciary is, and should remain, a thing apart from the political process. The basic structure of constitutional democracy, in his words,

involves a conceptual separation between (1) the constitution, which defines the rights of persons and groups to do things and defines the rules under which collective decisions are to be made, (2) the institutions of "the law," which adjudicate the conflicting claims made within this set of rights and rules, and (3) the collective decision-making process of the ordinary legislative variety, which presumably promotes "public good," but again within the rules laid down in the constitution. 2 I

This conception of the law in general, and the Supreme Court in constitutional adjudication in particular, as standing apart from and 
limiting the scope and intrusiveness of the political process has been shared by most legal commentators 3 / since at least the time of Alexander Hamilton. 4/ A quite different conception has been proposed by political scientists writing in the tradition of interestgroup analysis, notably Martin Shapiro. $5 /$ He argues that, like other organs of government, the Supreme Court is the agent of interest groups-in Shapiro's view, interest groups not represented adequately by other governmental organs. We are not convinced by Shapiro's effort to transform the Court into a political body. In particular, his conception leaves unexplained why it is that the Supreme Court, viewed as a political organ, should be systematically responsive to the least politically influential segments of the society.

We believe that economic analysis may hold the key to reconciling the notion of andependent judiciary with a conception of the political-governmental process that emphasizes the importance of interest groups in the formation of public policy. The reconciliation that we propose may seem at first paradoxical, for we grant that the judiciary is in an important sense independent of and dissimilar to the political branches of the government yet at the same time maintain that it is a necessary element in the successful functioning even of a government of interests and powers, as distinguished from a government that seeks to maximize some general notion of welfare or the public interest.

Article III of the U.S. Constitution provides for the appointment (rather than election) of federal judges, provides that they are to have life tenure, and forbids Congress to reduce their salaries while 
they are in office. These provisions, while they are as we shall see not airtight, were designed and have operated in practice to endow the federal judiciary with a substantial measure of independence from the wishes of Congress and the President. To a lesser degree, the same thing may be said of state and municipal judges, of judges in many other countries, and, for that matter, of judges at all levels, in America and elsewhere, long before Article III was conceived.

The existence of an independent judiciary seems inconsistent with--in fact profoundly threatening to--a political system in which public policy emerges from the struggle of interest groups to redistribute the wealth of the society in their favor, the view of the political process that underlies much of the recent economic work, as well as an older political-science literature, on the political system. The outcomes of the struggle can readily be nullified by unsympathetic judges--and why should judges be sympathetic to a process that simply ratifies political power rather than expresses principle? The Supreme Court's policy toward economic legislation during a period of roughly 50 years ending in the late 1930 's $6 /$ illustrates the power and proclivity of an independent judiciary to nullify the legislative results of interest-group politics.

We believe, however, that at a deeper level the independent judiciary is not only consistent with, but essential to, the interestgroup theory of government. Part I of this paper explains our theory of the independent judiciary. Part II discusses several implications of the theory, relating to administrative regulation, the form of interest-group legislation, the tenure of judges, and constitutional 
adjudication. The appendix to this paper presents an empirical analysis of judicial independence using data on Acts of Congress that have been held unconstitutional by the Supreme Court.

I. An Economic Theory of the Independent Judiciary

A. Legislative "Dea7s" and Judicial Independence

In the economists' version of the interest-group theory of government, legislation is supplied to groups or coalitions that outbid rival seekers of favorable legislation. $\underline{7}$ The price that the winning group bids is getermined both by the value of legislative protection to the group's members and the group's ability to overcome the free-rider problems that plague coalitions. Payment takes the form of campaign contributions, votes, implicit promises of future favors, and sometimes outright bribes. In short, legislation is "sold" by the legislature and "bought" by the-beneficiaries of the legislation.

Private sales, and other private contracts, carry legal sanctions for nonperformance. Where the performances of the buyer and seller are \#

not simultaneous, and th gparties are not constrained to act in good faith by a desire to obtain similar business in the future, the legal sanctions are likely to be an important factor in the decision to enter into the transaction. But there are no legal sanctions for the failure of a legislature to carry out its "bargain" with.an interest group. Suppose the airline industry obtains from Congress (as it did in 1938) legislation designed to foster monopoly pricing while preventing the entry of new competitors that such pricing would ordinarily attract. There is no legal mechanism analogous to a binding long-term contract 
by which the enacting Congress can prevent a subsequent Congress from amending the legislation in a, way unfavorable to the airlines, or indeed from repealing it altogether. Yet both the enacting Congress and the airlines, in procuring the legislation, may have incurred substantial expenses that would not prove worthwhile if the legislation were to be altered unfavorably or repealed within a few months or years. To be sure, congressional bad faith of this sort would reduce the present value of legislative protection to interest groups in the future, and hence the enacting Congressmen's welfare. Such a manifestation of congressional bad faith would, by reducing the value of legislative protection to interest groups, impose costs on the faithless Congressmen: the "price" they could demand for enacting such legislation would be lower. For many individual Congressmen, however, especially those who did not expect to remain in Congress for long, the benefits from repudiating a previous Congress' "deal" might outweigh the costs. And even if the good faith of the majority of Congressmen were assured, it would be insufficient to guarantee legislative stability in any case where the initial vote enacting the legislation was not one-sided. If the vote was close, the defection of only a few Congressmen, as a result of retirement or defeat at the polls, from the winning coalition might lead to a repeal in the next session of Congress, since the newly elected Congressmen would have no commitments to honor the "deals" of their predecessors. 8 /

The element of stability or continuity necessary to enable interest-group politics to operate in the legislative arena is supplied, 
in the first instance, by the procedural rules of the legislature, and in the second instance by the existence of an independent judiciary. The most significant of the procedural rules is the requirement that legislation (including amending or repealing legislation) must be enacted by a majority of the legislators voting. This requirement makes legislative enactment a difficult and time-consuming process because of the transaction costs involved in getting agreement among a larger number of individuals. $9 /$ Consequently, once a statute is passed, it is unlikely, given the press of other legislative business, to be substantially altered or repealed in the immediate future. Other characteristics of the legislative process also create resistance to both the speedy enactment of new laws and the repeal of old ones: bicameralism, the committee system, and fillibusters are important examples. Consider the tradition (now beginning to erode) of appointing committee chairmen on the basis of seniority. The use of seniority tends to channel chairmanships to holders of "safe" congressional seats-Congressmen whose tenure can be expected to be long and who are therefore more likely to honor the commitments made by Congress. 10/

The impediments to legislation have the effect of endowing legislation, once it is enacted, with a measure of durability. The result is to increase the value of and hence the demand for legislation. But there is an offsetting effect: by increasing negotiation costs and uncertainty the impediments reduce the productivity of expenditures on obtaining legislation in the first place. However, under plausible assumptions the increase in the value of legislation will exceed the increase in its 
cost, since a modest increase in the cost of enacting legislation could multiply many-fold the length of the period in which the legislation was expected to remain in force.

Legislation is not self-enforcing, however. If the people subject to a law refuse to obey it, recourse to the courts is necessary to enforce the law. A judiciary that was subservient to the current membership of the legislature could nullify legislation enacted in a previous session of the legislature. Suppose that Congress in year one "sells" the diary industry a heavy tax on margarine, but the next year the producers of margarine offer Congress generour inducements to remove the tax. Congress is unlikely to respond to this demand by enacting repealing legislation, due to the impediments to swift legislative action that we have discussed. But if the judges are the perfect agents of the current Congress, they will refuse to enforce the margarine tax, and the effect will be the same as legislative repeal. Although outright refusal to enforce a law is an extreme example, the limits of human foresight, the ambiguities of language, and the high cost of legislative deliberation combine to assure that most legislation will be enacted in a seriously incomplete form, with many areas of uncertainty left to be resolved by the courts. Insofar as judges are merely agents of the current legislature, they will utilize their considerable interpretive leeway to rewrite the legislation in conformity with the views of the current rather than the enacting legislature and they will thereby impair the "contract" between the enacting legislature and the group that procured the legislation. 
If we assume that an independent judiciary would, in contrast, interpret and apply legislation in accordance with the original legislative understanding 11/ (an assumption examined shortly) it follows that an independent judiciary facilitates rather than, as conventionally believed, limits the practice of interest-group politics. To be sure, like the constitutive rules of the legislative process, the independent judiciary increases the cost of enacting legislation in the first place. Being independent, the judges may (directly or indirectly) refuse to enforce legislation that they do not like and this possibility reduces the value of legislation to the group seeking it. But that is a necessary price to pay for a system in which interest groups will have incentives to invest in legislation that yields them benefits over an extended period of time.

B. A Formal Model

Before examining certain objections to the analysis, it will be helpful to present a more formal version of it. Let $d_{0} d_{1}$ in Figure I represent the demand curve of various groups for special-interest legislation (such as protective tariffs, import quotas, or minimum rate regulation) under the assumption that the benefits from such legislation will be limited to a single period, namely the term of the enacting legislature. The demand curve is negatively sloped because some groups will obtain greater benefits from protective legislation and accordingly will offer a higher price. $S_{0} S_{1}$ is the marginal cost curve of the legislature, viewed as the seller of special-interest legislation. The legislature's costs include the costs of drafting legislation (primarily the opportunity costs of the time spent by 
legislators in attending committee meetings, roll calls, etc.) and other expenses. 12/ The market for special-interest legislation will clear at point $E_{0}$ in Figure $I$, where $L_{0}$ units of legislation are produced. At $E_{0}$ all the gains from trade between interest groups and legislators will be fully exploited under the (restrictive) assumption that legislation is sold only for a single period. The dollar benefits after deducting the costs of writing the legislation will equal the area $d_{0} E_{0} S_{0}$, and are distributed between legislators and groups obtaining legislation, the simplest assumption being that the benefits received by legislators are proportional to the area $d_{0} E_{0} S_{0} \cdot 13 /$

[Insert Figure I about here]

Now let the gains from special-interest legislation extend beyond the period of the enacting legislature. To simplify, assume that the legislation will never be repealed and that the group benefited by its expects to obtain constant profits per period from the legislation. Then the maximum price the group will pay to obtain the legislation will equal the present value of those profits. In terms of Figure I, the relevant demand curve is now $D_{0} d_{1}$, which is a vertical multiple of the single-period demand curve. $14 /$ Assuming for the moment that it costs no more to enact permanent than single-period legislation and that legislative "deals" can be permanently enforced at zero cost, the new equilibrium position will be at $E_{2}$. This differs from the single-period model in two important respects. First, there is more special-interest legislation $\left(L_{2}\right.$ compared to $\left.L_{0}\right)$, since some legislation that was not profitable to enact when the return was received for only one period is 


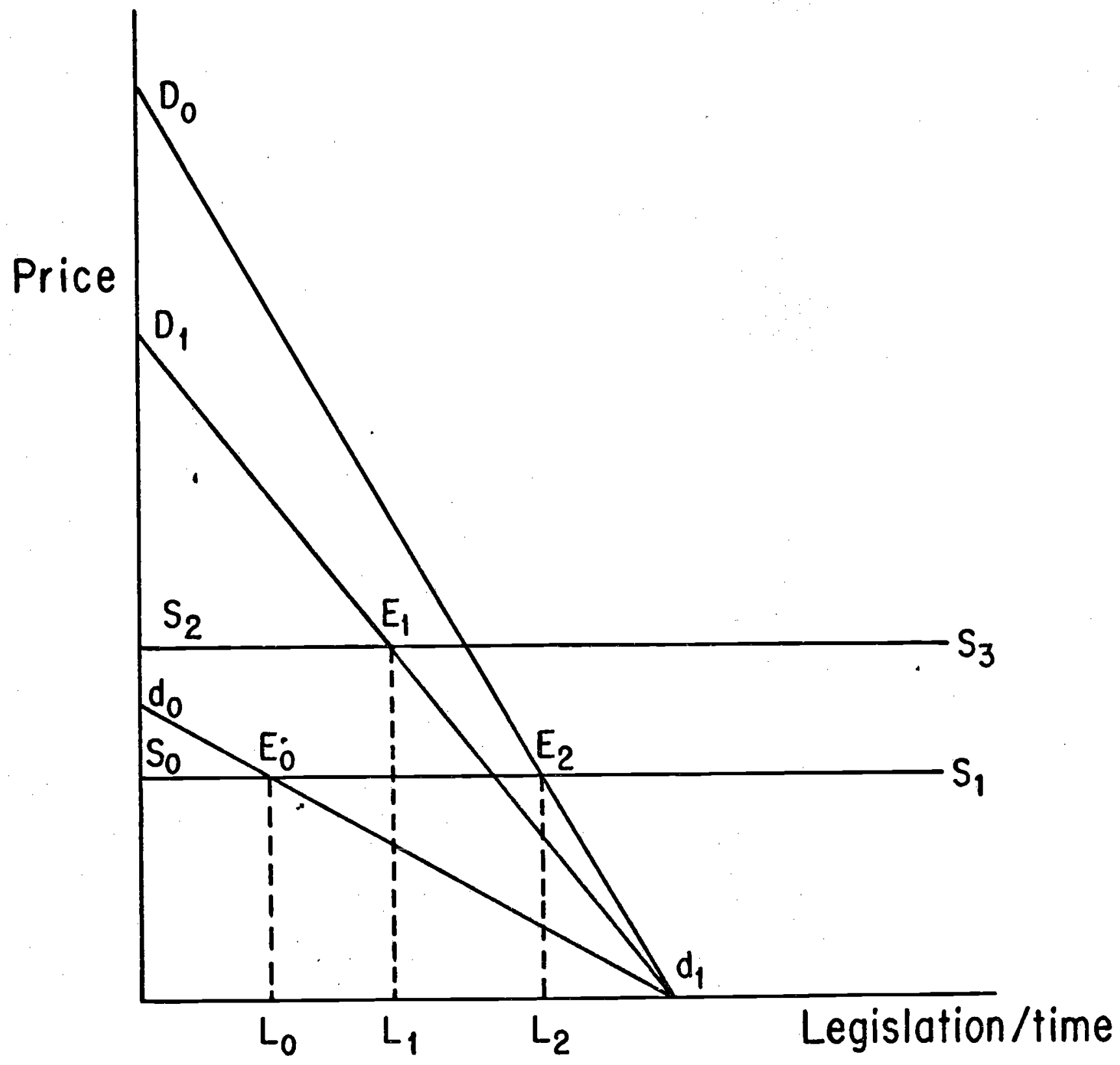

FIGURE I 
now profitable. 15 (Indeed, if $d_{0} d_{1}$ were everywhere below the marginal cost curve, there would have been no special-interest legislation at all in the single-period model.) Second, since the discounted benefits of the legislation as measured by the area $D_{0} E_{2} S_{0}$ exceed the singleperiod benefits, the "take" of the enacting legislature, which we assume to be proportional to the benefits of the legislation to the group procuring it, increases when legislation extends beyond one period.

Thus, the legislature has powerful incentives to devise methods of increasing the permanency of legislation. $16 /$ As we have seen, there are two complementary methods of doing this. The first involves establishing procedures for the enactment of legislation that increase the cost of repealing it; the second, the creation of an independent judiciary to enforce legislation in accordance with the intentions of the enacting legislature. In terms of Figure I, the effect of the internal procedures is to shift the marginal cost curve upwards to $\mathrm{S}_{2} \mathrm{~S}_{3}$ while at the same time shifting the dmeand curve to the right of $d_{0} d_{1}$. Internal procedures will presumably be added until the additional benefits of the legislature from increasing the demand for legislation are just equal to the additional costs of the procedures.

If, however, the judges served at the pleasure of the legislators, their decisions would presumably be in perfect harmony with the current legislature's wishes, and we would be back to the single-period model with demand curve $d_{0} d_{1}$ no matter how cumbersome were the internal procedures of the legislature. It is no answer that interest groups would simply pay for legislation on the installment plan--a sum each 
period in exchange for the continuation of the original "deal." The enacting legislature would still have an incentive to produce only $L_{0}$ units of legislation since it would not be compensated for additional units. As noted earlier, the legislature might find it unprofitable to "sell" any legislation at all unless the future benefits of the legislation could be capitalized and received by the enacting legislature. Finally, even if the costs of producing the legislation were zero, so that the number of "deals" was independent of whether or not the enacting legislature could appropriate future benefits, the legislature would still have a strong incentive to build durability into its legislation in order to capture some of those future benefits.

If the judiciary is independent, $17 /$ it can be expected, for reasons explained in the next subpart, to enforce existing statutes in accordance with the intent. of the enacting legislature. But while the combination of high legislative costs of repeal and an independent judiciary thus turns out to be an ingenious device for promoting the sale of long-term special-interest legislation, independence is not without its costs. The judiciary may decide not to enforce the deal worked out by the legislature. It may declare the law unconstitutional or interpret it in a manner that reduces the gains from the law to the group intended to benefit from it, since most sitting judges, hąving been apppointed in an earlier period, will "owe" nothing to the enacting legislature.

The cost of independence is shown in Figure I by the demand curve $D_{1} d_{1}$, which is lower than $D_{0} d_{1}$. The difference between the two curves is due to the positive probability in each future period that the 
returns from the special-interest legislation will not be forthcoming because of adverse judicial rulings. These expectations will be incorporated into the maximum price that groups are willing to pay for favorable legislation. Since judicial nullification of legislation has in fact been relatively infrequent, $18 /$ it seems reasonable to assume that $D_{1} d_{1}$ will lie substantially above $d_{0} d_{1}$, the single-period demand curve. This is illustrated in Table 1 , which shows the ratio of the multi-period to the single-period maximum price for several

[Insert Table 1 about here]

hypothetical values of the probability of judicial nullification, the number of time periods, and the interest rate. We assume that the single-period returns occur with certainty (since in / single-period be recalled, the judiciary is assumed to be the perfect agent of the enacting legislature), while the multi-period returns are subject to the risk of nullification in each period. 19/ If, for example, a 10 per cent interest rate and a / probability of nullification per period are assumed, the present value of the legislative returns (and hence the maximum price the interest group is willing to pay for favorable legislation) is between 2.8 and 2.9 times greater in the multi-period (10 or more periods) than in the single-period model. Overal1, the multi-period to single-period ratios range from 1.7 to 9.0 in Table 1 , the ratio being greater the lower the probability of nullification, the lower the interest rate, and the greater the number of time periods. These calculations indicate that there are substantially higher benefits from multi-period deals even when the probabilities of nullification are 
themselves substantial. In fact, in order for the single-period price to equal the multi-period price and thus for $d_{0} d_{1}$ to equal $D_{1} d_{1}$ in Figure I, the probability of nullification would have to be between .45 and .50 in each period. $20 /$

The equilibrium sale of legislation, which incorporates both the costs of the self-imposed rules on the legislative process and the expected "tax" resulting from the independence of the judiciary, occurs at $E_{1}$ in Figure $I$, where $L_{1}$ units of legislation are produced, yielding benefits equal to $D_{1} E_{1} S_{2}$ which are divided between the interest groups and the legislature. Even assuming that these benefits are greater than the area $d_{0} E_{0} S_{0}$, this solution is a second-best one. The benefits would be greater if the long-term commitments of the current legislature could be enforced at zero cost. With this possibility excluded, the independent judiciary serves the function of permitting some capitalization of future returns into the pockets of the current legislature. C. A Closer Look at the Concept of Judicial "Independence"

The reader may be troubled by the assumption that the "independent" judiciary is really independent of interest-group political pressures, by our failure to present an explicit theory of judicial behavior, and by the existence of alternative theories of the independence of the judiciary.

It is of course unrealistic to suppose the judiciary wholly independent of the current desires of the political branches. The legislature could refuse to appropriate funds to pay the judges' salaries; the executive could refuse to enforce judicial decrees. Short of outright confrontation, there are various methods by which 
the political branches can impose costs on the judiciary, such as budgetary harassment, $21 /$ tinkering with the courts' jurisdiction, and altering the composition of the judiciary by the creation of many new judgeships. Yet such devices have been resorted to infrequently, even in periods of intense hostility to judicial rulings. The reason, we conjecture, is the high costs of the available methods of harassment in relation to the benefits sought. The current legislature may want judicial interpretations that gut some existing laws, but if it tries to procure them by forms of coercion that impair the functioning of the judiciary across the board, it will impose costs on all who use the courts, including various politically effective groups and indeed the beneficiaries of whatever legislation the current legislature has enacted.

At the same time, the fact that the legislative and executive branches do have means of coercing the judiciary helps to explain why the self-interest of independent judges is promoted by enforcing legislation according to its original tenor. If courts are not valued highly, the imposition by the current legislature of coercive measures that impair the courts' effective functioning will not be perceived as highly costly, and such measures will therefore be imposed more often. The value (both social and private) of courts is a function in major part of the predictability of their decisions and decision according to the original meaning of a statute rather than according to the evershifting preferences of successive legislatures is probably an important source of that predictability, in part because such a decision is based 
on materials (for example, the congessional debates) available to all to study and base predictions of judicial behavior on. In short, the ability of courts to maintain their independence from the political branches may depend at least in part on their willingness to enforce the "contracts" of earlier legislatures according to the original understanding of the "contract."

There is, to be sure, the possibility that although the judiciary is independent of the political branches, interest groups will intervene directly with judges to undo the results of an earlier legislative process. However, the methods of imparting independence from the political branches of government also serve to reduce the possibility of direct or indirect bribery of the judges by interest groups. Life tenure--in circumstances where the job holder intends to remain in the job for the remainder of his active life--- 2 / reduces the likelihood of an important (because difficult to detect) form of bribery that consists of dangling prospects of future employment before the bribetaker. Life tenure also increases the expected penalty for bribery, assuming dismissal is a major sanction for bribery. $23 /$ other rules of the judicial process also operate to reduce the operation of interest groups in the judicial arena, notably the rules limiting ex parte contacts with judges and denying legal standing to groups, as distinct from the individuals or firms immediately affected in a narrow legal sense, by the legislation in question.

Not only is the assumption of independence plausible, but the judiciary in fact commonly behaves as if it were independent of the wishes of the current legislature. 24 / 
To be sure, this leaves open the question, what does determine the outcome of judicial decisions? As mentioned, there are constraints, imposed by the legislative and executive branches, that set the outer limits on judicial autonomy but they leave a broad area on which judicial behavior cannot be explained by reference to those constraints. Within this area, the development of an economic throry of judicial behavior is hampered by the studied efforts of society to divorce judicial rewards from the outcome of judicial decisions. A possibility is that judicial decision-making should be viewed as a consumption activity from the judge's standpoint. He decides in a certain way not because it will get him something else but because he derives personal satisfaction from preferring one party to the lawsuit over the other or one policy over another, a form of satisfaction that individuals routinely seek in a variety of areas. However, to develop this or any other theory of judicial behavior would carry us far beyond the scope of this paper, and is we believe unnecessary to it.

It remains to consider alternative explanations for the existence of the independent judiciary to the one proposed here. The commonest explanation is that an independent judiciary is necessary to enforce the Constitution against the legislative and executive branches of government. This is unconvincing. The English judiciary is also independent but English judges may not have--and certainly do not exercise--the power to invalidate acts of Parliament. In most other societies as well, the judiciary has considerable independence (save in politically very sensitive areas, mainly involving internal security) yet no power to invalidate legislative action. 
Another possible explanation is that an independent judiciary minimizes the costs of legal procedure. Life tenure reduces turnover and thereby imparts greater predictability to judicial decisionmaking. The longer a judge is on the bench, the easier it becomes to predict his decisions in many different kinds of cases. Also, long tenure imparts valuable experience to a judge and thereby increases his efficiency. Finally, as just mentioned, long tenure reduces the danger of bribery--a danger that exists quite independently of the existence of interest groups. What these points overlook, however, is"that while long judicial service may be socially desirable, granting life tenure and a guaranteed salary is not an efficient method of optimizing the length of judicial service. (Observe that legislators are not employed on any such basis, though most of the arguments just noted also apply to them.) A more efficient method would be to pay high salaries contingent on satisfactory performance. This would avoid the disincentive effects of divorcing tenure and compensation from performance and would be clearly preferable to the life-tenure system-were it not for the exigencies of an interest-group system of government. 1I. Postive Implications of the Economic Theory of the Independent Judiciary

A. Administrative Regulation

Administrative agencies such as the Interstate Commerce Commission and the Civil Aeronautics Board are examples of what we may call the "dependent" judiciary. Congress, lacking the time to regulate railroad rates in detail, establishes an Interstate Commerce Commission to do so. The Commission has some indicia of independence but many fewer than the federal courts; in particular, its members serve for limited terms and 
18.

turnover is in fact quite rapid. Furthermore, the fact that it has a much more specialized jurisdiction than the federal courts facilitates congressional surveillance and direction through the appropriations process in a way that would be infeasible with respect to the courts.

The analysis in Part I of this paper suggests three propositions concerning administrative regulation which seem consistent with at least casual observation:

1. Administrative agencies will be established most frequently when the probability of de facto judicial nullification of legislation is high (for example, during the New Deal, when the courts were hostile to federal economic regulations $\frac{25 /}{)}$. This is because the ability of courts to nullify legislation, especially by adverse factfinding in enforcement proceedings, can be curtailed by consigning the factfinding function to an administrative agency, which will tend to be more subservient to the legislature.

2. The legislature will, however, preserve judicial review of administrative determinations $\underline{26 /}$ in order to assure that the agency, in its eagerness to serve the current legislature, will not stray too far from the terms of the legislative "deal" establishing the regulatory program that the agency administers.

3. Since, however, judicial review cannot be expected to be wholly effective, we expect--and find--that administrative adjudication is far less consistent over time than judicial. (A related point is that precedent plays a smaller role in administrative than in judicial decision-making.) This follows directly from the relatively dependent character of administrative judging. 


\section{B. The Form of Interest Group Legislation}

We have thus far treated the legislative act as complete at the time of enactment--all of the benefits of the legislation are assumed to flow without subsequent legislative action. Yet some legislation is ineffective without substantial annual appropriations by the legislature, either to pay a periodic subsidy or to defray the expenses of a public agency charged with enforcing the statute. Legislation incomplete in this sense at the time of enactment is much less valuable to its beneficiaries than legislation that is complete when enacted; in the first case, the beneficiaries may have to "buy" the legislation anew every year. In terms of our formal model, we are in effect back at the single-period demand curve in Figure 1. In order to enable the enacting legislature to appropriate part of the future benefits, we would expect--and we find--that interest-group legislation is typically cast in a form that avoids the necessity for substantial annual appropriations. Legislation setting up regulatory agencies that use power over rates and entry to redistribute wealth is an important example: the annual budgets of these agencies are very small in relation to the redistributions that they effect. 27 Not only is regulation used much more of ten than direct subsidization to benefit interest groups, but when direct subsidies are used their funding is often made independent of further legislative action by the device of the earmarked tax, as in the interstate-highway and social-security programs.

The problem of legislation that requires substantial annual appropriations to maintain its effectiveness is forcefully illustrated by the experience with Prohibition. The supporters of Prohibition were able to 
obtain a constitutional amendment, normally as we shall see $\stackrel{28 /}{a}$ particularly durable form of interest-group legislation. However, unlike many other forms of regulation, prohibiting the sale of alcoholic beverages required a massive law-enforcement effort. This is strikingly illustrated in Table 2, which shows how Prohibition cases came to dominate the dockets of the federal courts. Of course

subsequent Congresses could have appropriated the sums necessary to increase the number of federal judges, prosecutors, customs inspectors, etc. to levels at which Prohibition would have been effectively enforced, but they were unwilling to do so. The result was that the constitutional amendment was effectively nullified, and it was repealed in 1933 after having been in effect for only 13 years. Constitutional amendments 
21.

that do not require substantial annual appropriations to enforce (e.g., the First Amendment) have proved a good deal more durable. 29/

An alternative to both annual subsidies and regulatory legislation would be the payment of a single lump sum to the interest group in the first period, a sum equal to the discounted present value of the annual subsidies or regulatory protection. Here, it would seem, the transaction would be complete in the first period and there would be no need to have any enforcement mechanism. However, if legislative enactment were a cheap and speedy process or the judges were the agents of the legislators, the interest group that had obtained the lump-sum payment would have no protection against the legislature's taxing away the entire payment in the second period, either by the levying of a special tax or by the courts' interpreting existing tax laws unequally.

C. The Determinants of Judicial Tenure

The value of judicia? independence is a function of the number of periods over which the returns from special-interest legislation accrue. Since an independent judiciary is, as we have seen, a source of costs as well as benefits to the legislature, we would expect the judiciary to be less independent the shorter the expected duration of specialinterest legislation. This may explain certain differences that one observes in the selection and tenure of judges at the federal, state, and local levels of government. As we progress down this ladder, we find in general shorter terms for judges and greater reliance on election rather than appointment as the method of selecting judges. This diminishing 
judicial independence is consistent with the fact that, the more confined or local is the jurisdiction of a legislature, the less scope it will have for enacting protective legislation. $30 /$ There is more competition for residents among cities and towns than among states, and among states than among countries, because from the resident's standpoint different cities are better substitutes for one another than different states, and different states better substitutes than different countries. Citizen mobility limits the effectiveness to schemes of redistributing weal th from one group to another at the state and local levels. Also, the regulation of a product or service is less effective the more limited the jurisdiction of the regulatory authority, because the providers are more mobile within a more limited area.

Thus it is hardly surprising that many federal regulatory schemes, such as railroad-regulation, arose from the debris of state regulatory attempts and that much state regulation came about as a result of failures of regulation at the municipal level. But this means that the importance of an independent judiciary to the practice of interestgroup politics declines as we move from regulation that is less local to regulation that is more local. The interest groups will not seek durable compacts from state and local legislatures anyway, so why should the political branches pay the price of an independent judiciary?

Another situation in which the independent judiciary will be less valuable to the political system is where legislators, despite having to stand for reelection every few years, in fact enjoy a long 
enough tenure in office for interest groups to be willing to accept long-term commitments from them. In this situation, an independent judiciary may not be very attractive to the legislature; its value as an enforcement agency will be slight and may well be outweighed by $i$ ts costs in potential nullification of legislative compacts. Short of eliminating the independence of the judiciary, the political branches can limit the consequences of that independence either (1) by expanding the size of the judiciary so as to be able to appoint a substantial number of new judges whose policy views will be compatible with those of the current legislature, or (2) by filling vacancies as they arise with older judges, whose expected terms of office will be short (shorter, perhaps, than those of the legislators). If this analysis is correct, one would expect an inverse relationship between legislative tenure and judicial tenture. That is, the longer the tenure of the legislatores, the greater will be judicial turnover, persumably brought about by election of judges or by appointment of older people to the bench. $31 /$

D. The Constitution and the Independent Judiciary

Earlier we rejected the suggestion that the existence of an independent judiciary is best explained in terms of its role in enforcing the Constitution. Nonetheless, the role of the courts in enforcing constitutional provisions is an important one on which the analysis in this paper casts some light. We have argued that the existence of an independent judiciary and the constitutive rules of legislative bodies (such as the requirement of a majority vote to 
enact legislation) are methods of imparting durability to an initial legislative judgment protecting some group. A constitutional right is simply another device for doing the same thing. Since such a right is much more difficult to retract than a statutory right--the procedures for constitutional amendment being so costly and timeconsuming--a constitutional provision confers more durable protection than is possible by ordinary legislative action. But enforcement by an independent judiciary remains necessary. Otherwise the constitutional provision would be continuously reinterpreted to accord with the preferences of the current legislators.

In the view proposed here, the Constitution has two purposes. One is to establish the ground rules for a system of interest-group politics; Article III is to be understood in this light. The second is to confer protective legislation of a peculiarly durable kind on those specially effective interest groups that are able and willing to incur the costs necessary to obtain a constititional provision in their favor. 321

Such a view has important implications for a number of constitutional controversies; we shall mention three here.

1. It is sometimes suggested that the protection of freedom of speech and of the press by the First Amendment should be limited to political expression, on the theory that the purpose of the First Amendment is to protect the electoral process by which members of Congress and the President are selected. 33/ However, a broader view of the scope of the First Amendment may be quite consistent with the 
approach taken here, for it would be congenial to that approach to view the First Amendment as a form of protective legislation extracted by an interest group consisting of publishers, journalists, pamphleteers, and others who derive pecuniary and nonpecuniary income from publication and advocacy of various sorts. $34 /$

2. The question has sometimes been raised whether it is not a perversion of constitutional principle to invoke a constitutional provision on behalf of a majority rather than a minority group, as in cases challenging "reverse" discrimination (for example, preferring blacks to whites) or--a more clear-cut example--cases challenging schemes of legislative malapportionment that have been adopted by popular referendum. From the standpoint of interest group analysis adopted in this paper, it is a detail whether the group comprises more or less than half of the voting population. Indeed, because a large group will often be politically less effective than a small one, due to the higher costs of collective action to the large group, such a group may benefit substantially from obtaining constitutional protection against legislative regulation--though by the same token it may find it difficult to obtain such protection in the first place. More broadly, our interest-group analysis casts doubt on the conventional view of constitutional lawyers that the Constitution is designed to protect the powerless, unrepresented elements of society. In a view of the governmental process as one in which the courts and Constitution play an integral role in a system of interest-group politics, the Constitution can more accurately be described as 
designed to protect groups sufficiently powerful to obtain constitutional protection for their interests. $35 /$ This of course does not explain why the "Warren Court" interpreted the Constitution as conferring extraordinary rights on the common criminal. There is considerable doubt whether these rights were intended by the framers of the Constitution and its amendments and perhaps this episode is best understood as an example of judicial independence. But we do not pretend to have developed a complete theory of the Supreme Court's behavior.

3. There is a long-standing debate over the question whether the Supreme Court should use the due process and equal protection clauses of the Constitution to strike down legislation that, even though it does not infringe upon a specific constitutional right such as freedom of speech, is unreasonable as judged by some general criterion of social welfare or public interest. It should not, and would not to the extent that the view suggested here--that the court's role is to enforce the specific interests protected by the Constitution rather than to act as a general brake on legislation promoting "factions" 36/ (special interest)--is correct. And, in general, the Court has not acted as a general brake on special-interest legislation, as the growth of the welfare state attests. The view that the Court's function is to promote or assure the consistency of the legislative product with the public interest, $37 /$ besides placing an enormous cloud over legislative activity in general, implies that the Court and the Constitution are outside of the structure of interestgroup politics, whereas we have tried to show that they are integral elements of that structure. 
This paper has sketched an approach to the question of the independent judiciary that enables a seeming anomaly in the older political-science and newer economic theory of the political process as a struggle among interest groups to be incorporated as an essential element of that theory. Our analysis has certain positive implications with respect to the structure of government that seem consistent with observed reality. It also has, as we have just seen, normative implications with respect to constitutional interpretation.

A striking element of our approach is that although we view the independent judiciary as an essential component in a system of interest-group politics, we do not view the judiciary as itself "political" in the sense suggested by Martin Shapiro $38 /$ and other debunkers of the idea of a genuinely independent judiciary. Our view of how the courts operate is closer to that of the legal commentators who extol the courts as "above" politics. $39 /$ Where we differ from these commentators is in not venerating the courts as repositories of some special wisdom, integrity, morality, or commitment to principle. In our view the courts do not enforce the moral law or ideals of neutrality, justice, or fairness; they enforce the "deals" made by effective interest groups with earlier legislatures. $40 /$ of course, since the judges are independent, an appeal to principles may be effective courtroom or law-review advocacy. 
Appendix

\section{Some Empirical Tests of Judicial Independence}

We have argued in this paper that an independent judiciary imposes expected costs on the sale of legislation. The possibility that the judiciary will not enforce the deals worked out by the legislature reduces the expected value of legislation, which in turn reduces the benefits to the groups procuring the legislation and the payments to the enacting legislators. Thus, the degree to which the courts overturn legislative deals is of critical importance in evaluating the usefulness of the hypothesis that independent judiciary fosters interest group politics. If the courts were sufficiently unreliable, the expected benefits from the sale of multi-period legislation, made possible by judicial independence, would not offset the costs of the legislative deals that were frustrated by the courts. And if this were the case, one would have to search further for an explanation of judicial independence.

The question of judicial unreliability or the costs of independence is amenable to empirical analys is although what follows must be viewed as a crude and preliminary attempt. We focus on a single measure of unreliability--the number of acts of Congress that have been held unconsititional by the Surpeme Court. Nullification is an extreme example of judicial unreliability", and for this reason is likely to be deficient as an overall measure of the costs of judicial independence. $41 /$ Nevertheless, it is the only measure that 
is readily available, and the development of a more suitable measure is beyond the scope of this paper.

Ninety-seven acts of Congress were held unconstitutional in whole or in part in the period 1789-1972, or an average of about one per term of Congress. $42 /$ Figure II indicates, however, that there has been a great deal of variability over time in the number of Supreme Court nullifications per term of Congress. Only two acts were nullified in the 1789-1864 period while 11 were nullified in the next 15 years. Three peaks in nullification activity are observable: 1920-1924 (11 nullifications in the 66th-68th Congresses); 1935-1936 (10 nullifications in the 74th Congress); and 1963-1972 (25 nullifications in the 88th-92nd Congresses). Between the latter two peaks, the number of nullifications diminished sharply (5 nullifications in the 1937-1962 periód).

What are the overall costs imposed by nullifications on the political process whereby legislation is bought and sold? Two inferences from the data lead us to believe that these costs are minimal. First, in comparison to the total number of public bills enacted by Congress, the number of nullifications is insignificant: 97 nullifications out of a total of more than 38,000 acts suggests an average probability of nullification per act of about .0026 . Even in the peak nullification period, 1935-1936, only nine out of the 1,526 statutes enacted between 1933 and 1936 were declared unconstitutional. 43/ Probabilities of such a small magnitude would seem unlikely to deter significantly the enactment of special-interest legislation. $44 /$ 
FIGURE II

Appendix 2a

Second, the nullification data take no account of the time span between passage of a statute and its nullification. A Supreme Court that in 1970 nullified a provision of a statute passed 61 years earlier would not be imposing substantial costs (discounted back to 1909) on the groups that originally procured the statute. 45 / Legislation that lasts 61 years is of sufficient durability to allow the full benefits of the deal to have been captured by the groups involved. So long a lag between passage and nullification is atypical, however. Thirty-eight acts were nullified within four years of their enactmen't, 58 within eight years, and 76 within 12 years. Only seven acts were more than 25 years old at the time of their nullification. $46 /$ However, even an act that lasts eight or ten years has sufficient durability to enable the bulk of the present value of $i$ ts benefits to be appropriated. $47 /$ If we restrict the sample to acts nullified within eight years of passage (because these are likely to have imposed the largest costs on the groups procuring the acts), not only does the number of nullifications fall by 40 per cent (from 97 to 58) but the time pattern of nullification changes in one interesting respect. The recent period, 1963-1973, is no longer a period of peak nullification activity (see Figure II). Of the 27 nullifications in this period, only nine took place within eight years of enactment. $48 /$

Multiple regression analysis can be used to estimate the influence that various factors have had on the frequency of Supreme Court nullifications and on the time lag between enactment and nullification of an act. The variables included in the regression analysis are as follows: 
$N_{t}$ : number of nullifications per congressional term.

$N_{t} 8$ : number of nullifications per term of acts passed within last eight years.

$N_{t}{ }^{16}$ : number of nullifications per term of acts passed within last 16 years.

$L A G_{j}:$ number of years between enactment and nullification for each of the $j$ nullifications $(j=1, \ldots$. . 95) between 1789 and 1972 .

AGE $_{t}$ : average age of the Supreme Court judges at the end of each congressional term.

TEN $_{t}$ : average tenure of the Supreme Court judges at the end of each congressional term.

BILL $_{t}^{i}$ : number of public bijls passed by Congress within the last $i$ years. Note that $i=8$ when the dependent variable is $N_{t}^{8}$ and $i=16$ when the dependent variable is either $\mathrm{N}_{t}$ or $\mathrm{N}_{t}^{16}$.

PAR $_{\mathrm{t}}$ : dummy variable that takes the value 1 if the political party of the President and the majority party of both the House and Senate are the same, and 0 if the President's party is different from the majority party of either the House and Senate.

DIS $_{j}$ : number of dissenting votes in the Supreme Court for each of the $j$ nullifications.

$t$ : identity of Congress ( $t$ runs from ist to 92 nd Congress). 
Multiple regression equations were estimated on the three dependent variables, $N_{t}^{8}, N_{t}^{16}$, and $N_{t}$, over the period 1789-1972. The specification of the $N_{t}^{8}$ regression is of the following form:

$$
N_{t}^{8}=\alpha+\beta_{1} A G E_{t}+\beta_{2} T N_{t}+\beta_{3} P A_{t}+\beta_{4} B I L L_{t}^{8}+u .
$$

The $N_{t}{ }^{16}$ and $N_{t}$ specifications are identical to (1) except that BILL $_{t}{ }^{16}$ replaces BILL $_{t}{ }^{8}$. The model of legal decision making that underlies the above equation is basically a variant of the economist's theorem that when the costs rise from engaging in certain behavior or the gains fall, the frequency of such behavior declines. Accrodingly, AGE is expected to have a positive effect on the rate of nullifications. 01 der judges, with fewer active years ahead, will be less susceptible to legislative or executive "bribery" in the form of promotions to higher office and are more likely to view their present position as a terminal one. Hence older judges will exercise their greater "independence" by nullifying more acts. The effect of the TEN variable is less certain than AGE. We expect that recently appointed judges will be more indebted to the current legislature and executive, and hence will be less likely to nullify the acts of their benefactors, but on the other hand, judges with less tenure will be less indebted to more distant Congresses. Hence TEN should have a positive effect on nullifications only if the nullification variable is restricted to acts that have been nullified within, for example, eight years of passage. $49 /$ PAR is included in the regression analysis to test the hypothesis that the court is less likely to demonstrate independence and hence nullify laws the less 
conflict there is between the executive and Congress. A crude measure of this conflict is whether the President's party is the same as the majority party of Congress. Thus we expect a negative sign on the PAR variable. Since the dependent variable is the number of nullifications while the model generates hypotheses on nullification propensities, we have included the number of bills passed (BILL ${ }^{i}$ ) as an independent variable in the regression. Thus, holding $\mathrm{BILL}^{i}$ constant implies that variations in nullifications reflect differences in the nullification propensities of the court.

Table 3 presents the regression results on three nullification variables- $-N_{t}^{8}$ (acts 8 years old or less), $N_{t}^{16}$ (acts 16 years old or less), and $N_{t}$ (all acts). Equations 2.1 - 2.3 are for the period 1789-1972, 50/ and equations $2.4-2.6$ are for a narrower set of observations, the 39th-92nd Congresses. $51 /$

Overall the regression results are inconclusive. The age variable behaves as predicted but is statistically significant only in the equations that include the full set of observations. In contrast, the tenure variable is insignificant when all observations are included but significant in the $N_{t}^{16}$ and $N_{t}$ regressions that are estimated on the 39 th-92nd terms. And the positive and significant effect of tenure in equations 2.5 and 2.6 compared to its insignificant effect in 2.4 is contrary to the prediction that the strongest positive impact of tenure should be observed in the $\mathrm{N}_{t}^{8}$ regressions.

One difficulty in estimating the separate effects of AGE and TEN in the same regression is that the two variables are highly correlated. 
This is particularly true in the regressions limited to the 39 th92nd Congressional terms where the correlation between AGE and TEN is .70. When TEN is excluded from equations 2.4-2.6, the AGE variable becomes highly significant. And similarly, when AGE is excluded from 2.4-2.6, the significance of TEN improves. $\underline{53 /}$ of the two remaining variables in the regression analysis, PAR is insignificant in all six regressions while BILL $^{i}$ is significant in two of the six. In sum, except for the AGE variables the results of the regression analysis yield little support for a theory of legal decision-making that hypothesizes that the observed degree of judicial independence is a function of the costs and benefits to the judiciary of exercising independence. It would be premature, however, to abandon the theory since our measures of costs and benefits (age, tenure, political party of executive and Congress) and our measure of independence (nullifications) are highly imperfect.

Our second empirical test is an analysis of the determinants of the time lag ( $L A G$ ) between the passage of a bill and its nullification. Here each of the 95 acts nullified.between 1789 and 1972 is an observation in the regression analysis. The regression specification is

$$
\text { In } L A G_{j}=\alpha+\beta_{1} A G E_{j}+\beta_{2} \text { TEN }_{j}+\beta_{3} \text { PAR }_{j}+\beta_{4} D I S_{j}+\beta_{5} t_{k}+\beta_{6} N+u
$$

where the LAG variable is in logarithmic form. $54 /$ Based on the theory outlined earlier, we would expect both $A G E$ and TEN to have negative effects on the LAG variable. Since the nullification of older acts is less costly to long-term legislative deals (because most of the present value of benefits are still being received by groups procuring 
the act), the younger the judges are, the more susceptible they will be to legislative and executive "bribery" and pressure and the less likely they will be to nullify recent congressional acts. Similarly, as average tenure diminishes the court will be more indebted to recent Congresses and less to past Congresses, making the Court less likely to nullify acts of the former and more likely to nullify acts of the latter. We expect PAR to have a positive effect on LAG because the greater the conflect between the executive and legislature, as measured by PAR, the less effective the two branches will be in bringing joint pressure on the Court not to nullify recent acts. We have no strong a priori predictions on the three remaining variables, DIS, $t$ and $N$, in equation (2). $N$ tests whether there is a systematic effect on the time lag when more acts are nullified per term; $t$ tests whether there has been, a trend over time in the age of acts nullified; and DIS tests whether the degree of conflict within the Court (as measured by the number of dissenting votes) varies with the age of the act nullified.

Equation 2.7 of Table 3 presents the LAG regression. AGE behaves as predicted--younger judges are less likely to nullify more recent acts--though its effect is only marginally significant. TEN is significant but its effect is contrary to our prediction. PAR and DIS are not significant. Both the $t$ and $N$ variables are highly significant. Here we find that the more recent the Congress, the greater the average age of the acts nullified; and the more acts nullified per term, the less is the average age of the acts nullified. $55 /$ 
* This study has been supported by a grant from the National Science Foundation to the National Bureau of Economic Research for research in law and economics. The paper is not an official Bureau publication since it has not yet undergone the full critical review accorded Bureau publications, including review by the Bureau's Board of Directors.

1. We define an "independent" judiciary as one that does not make decisions on the basis of the sorts of political factors (for the example,/electoral strength of the people affected by a decision) that would influence and in most cases control the decision were it to be made by a legislative body such as the U.S. Congress.

2. James M. Buchanan, Good Economics--Bad Law, 60 Va. L. Rev. 451, 491 (1974). See also Frank H. Knight, Economic Theory and Nationalism, in The Ethics of Competition and Other Essays 277-79, 299 (1935); F. A. Hayek, The Constitution of Liberty, ch. $12(1960)$.

3. See, for example, Gerald Gunther, The Subtle Vices of the "Passive Virtues"--A Comment on Principle and Expediency in Judicial Review, 64 Colum. L. Rev. 1 (1964).

4. See The Federalist No. 78. 
5. Martin Shapiro, Law and Politics in the Supreme Court: New Approaches to Political Jurisprudence (1964)。Cf. Robert A. Dah1, Decision-Making in a Democracy: The Supreme Court as a National Policy-Maker, 5 J.Pub. Law 279, 294 (1957) (comparing Supreme Court to "a powerful committee chairman in Congress"). For a penetrating critique of the legal and political-science literature dealing with the relationship between the Supreme Court and politics see Jan G. Deutsch, Neutrality, Legitimacy, and the Supreme Court: Some Intersections Between La' and Political Science, 20 Stan. L. Rev. 169 (1968).

6. See Robert G. McCloskey, Economic Due Process and the Supreme Court: An Exhumation and Reburial, 1962 Sup. Ct. Rev. 34.

7. See George J. Stigler, The Theory of Economic Regulation, 2 Bell J. Econ. \& Man. Sci. 3 (1971), and, for a general review of the literature, Richard A. Posner, Theories of Economic Regulation, 5 Bell J.Econ。\& Man。Sci. 335 (1974).

8. Presumably, the new Congressmen could be "bought" by the group that had obtained favorable legislation from their predecessors. But this is simply an example of having to pay twice for a single good. We consider later the alternative possibility of paying for favorable legislation on an installment basis. 
9. On the costs of legislative enactment see Isaac Ehrlich \& Richard A. Posner, An Economic Analysis of Legal Rulemaking, 3 J. Leg. Studies 257, 267 (1974).

10. At the beginning of the 93rd Congress (January 1973) the average Senate Committee chairman had been a member of Congress for 20 (continuous) years. The corresponding figure for the House of Representatives was 26.4. A partially offsetting factor is that when seniority is the basis of selection, chairmanships tend to be awarded to older members, who may not have a long period of continued service ahead of them. Thus, two of the 17 Senate committees in 1973 (and six of the 21. House committees) had new chairmen. The chairmen of the remaining 15 Senate committees had been chairmen an average of 6.1 (continuous) years; the average was the same for the House chairmen. Note that the maximum tenure of a chairman in 1973 would have been 18 continuous years since there had been a democratic majority in Congress since 1955. The source of these statistics is 3 Congressional Quarterly Service, Congress and the Nation: A Review of Government and Politics 1969-1972, at 52a-55a.

11. This does not imply literal-minded or otherwise inflexible interpretation of the legislation. On the contrary, judicial interpretations that enable a law to survive the vicissitudes of unforeseen technical or economic changes that might effectively nullify the law were it not interpreted flexibly are perfectly consistent with the idea of an independent judiciary. 
12. The analysis does not depend on the shape of the marginal cost curve (assumed in Figure I to be horizontal) or on the assumption that there are positive costs of selling legislation.

13. Our assumption that the market clears when gains from trade are fully exploited rules out a monopoly output, which would be less than $L_{0}$. But it does not imply that legislators are perfectly discriminating monopolists (in which event they would cover their costs and receive in addition the entire area $\left.\mathrm{dE}_{0} \mathrm{~S}\right)$; a competitive market in the sale of legislation is possible. Such a market would also clear at $E_{0}$ but the area $\mathrm{dE}_{0} \mathrm{~S}$ would be received by purchasers, contrary to our assumption that legislators receive part of $\mathrm{dE}_{0} \mathrm{~S}_{0}$. (If marginal costs in Figure I were rising, legislators would receive an amount in excess of their costs even in the purely competitive case.) An additional question is whether the benefits in Figure I will be competed away by expenditures to obtain legislative seats or expenditures on lawyers, lobbyists, etc.

Since the results we obtain in this paper are unaffected by which assumption we make (that is, monopoly, perfect price discrimination, competition with and wi thout rents, gross benefits versus net benefits), we do not pursue these questions any further. 
14. When legislation lasts for more than one period, the demand curve faced by the current (enacting) legislature will also depend on the amount of legislation sold earlier. Previous legislatures will have already exploited many attractive opportunities that the current legislature cannot resell again. Thus $D_{0} d_{1}$ in Figure $I$ will be a vertical multiple of a single-period curve that is lower than $d_{0} d_{1}$ since the latter was constructed on the assumption that legislation lasted only a single period (implying that the current legislature was not encumbered by past deals). In the subsequent analys is, which compared $D_{0} d_{1}$ to $d_{0} d_{1}$, we assume (contrary to the initial exposition) that both demand curves are constructed on the assumption that multi-period deals were possible in the past and that some of these deals extend into the term of the current legislature.

15. This conclusion depends critically on the modification in the model (see supra note 14 ) whereby $d_{0} d_{1}$ allows for multi-period deals in the past. If $d_{0} d_{1}$ did not, then it is possible that the current legislature would face a multi-period demand curve that was lower than $d_{0} d_{1}$, causing the multi-period quantity of legislation to fall short of the single-period quantity. In the limit, if all profitable deals had been exploited by the time the current legislature was elected, and technological and demand changes did not yield new opportunities, the current legislature would not be able to make any multi-period (or for that matter single-period) deals. In comparison, if past and 
15 continued

present deals are limited to a single period, the current legislature might find many profitable single-period deals available. Even if $D_{0} d_{1}$ were lower than $d_{0} d_{1}$ (as originally derived), the total stock of special-interest legislation existing at a moment in time would still be greater if multiperiod deals were permitted. The time distribution of these deals would differ, however, as most would have been arranged by earlier legislatures with few deals remaining for the current legislature to make. In this event, the main beneficiaries of multi-period deals would be past legislators.

Thus, our model provides an explanation for the original formation of an independent judiciary since early legislatures, not encumbered by past deals, would favor an institution--the independent judiciary--that fostered the making of long-term contracts. It is also consistent with the current legislature's favoring an independent judiciary; provided that one takes past legislative deals as given and generally beyond the reach of current legislatures, the current legislature would also benefit from being able to make multi-period deals compared to being restricted to single-period ones.

16. We consider in Part IIR, infra, the question why optimum specialinterest legislation does not take the form of a single lump sum that is paid to the interest group by the legislature in the first period. 
17. See note 1 supra.

18. For example, between 1789 and 1972 the Supreme Court held only 97 acts of Congress unconstitutional. This figure provides, of course, only a crude measure of judicial nullification and hence the "unreliability" of the federal courts, since they exclude both unfavorable interpretations (which may be made by the lower courts as well as by the Supreme Court) that stop shart of declaring a statute unconstitutional and statutes that are never enacted in the first place because prior judicial rulings indicate a high probability that they will be invalidated. See the appendix to this article for a further discussion of, and attempt to measure, the effect of the Court's power to nullify legislation or the costs of an independent judiciary.

19. The single-period and multi-period expected maximum prices are respectively:

$$
\begin{aligned}
& z_{1}=\frac{R}{(1+i)} \\
& z_{2}=\frac{R p}{(1+i-p)}\left(1-\frac{p^{\top}}{(1+i)^{\top}}\right),
\end{aligned}
$$

where $R$ is the return per period from the special-interest legislation, $i$ is the interest rate, $(1-p)^{*}$ is the probability of judicial nullification of the legislation, and $T$ is the number of time periods. $R, i$ and $p$ are assumed constant per period. A constant $p$ implies an increasing probability that 
19 continued

future returns will not be forthcoming since $p^{t}$ (where $t=1, \ldots$, T)--the present probability that the returns will be received in any future period $t--i s$ a decreasing function of $t$. The assumption that $p$ is constant is probably incorrect. The importance of precedent in judicial decision-making is likely to produce probabilities $(p)$ in periods $2, \ldots . T$ that are close to one proved that the legislation is upheld in its initial test in the first period. This implies that the calculation in Table 1 understate the multi-period to single-period ratios.

20. This is calculated by setting $Z_{1}$ equal to $Z_{T}$, fixing $i$ and $T$ within the range given by Table 1 , and solving for $p$.

21. Refusing to raise judges' salaries in the face of inflation, refusing to make adequate appropriations for supporting personnel, etc.

22. De facto life tenure or an approximation of it is the rule for the overwhelming majority of Supreme Court Justices. Of the 94 former Justices, 55 died in office or within one year of leaving office, and 24 more died within 10 years of leaving office after having retired at an average age of 71 . The remaining 15 , several of whom are still living, left the Court at an average age of 61 . 
22 continued

(See 1975 World Almanac and Book of Facts 770.) We have also compiled data on the turnover rate every two years since 1885 of all federal court judges. Turnover data can be used to estimate average tenure on the job, provided that a period is selected in which the number of judges remains approximately constant. Unfortunately, the latter condition is rarely met as the number of federal court judges (including retired but still sitting judges) has risen from 74 in 1885 to 635 in 1975 . However, the increase was relatively modes (297 to 348) from 1949 to 1965, and the average two-year turnover rate in the period was .0787 which converts into an average tenure on the bench per judge of 25.4 years (2/.0787). Moreover, most of the turnover has come from deaths (particularly of retired but still sitting judges) rather than from resignations. Therefore, our assumption that a federal judicial appointment is generally a terminal job is consistent with the evidence on Supreme Court and other federal court judges.

23. Cf. Gary S. Becker \& George J. Stigler, Law Enforcement, Malfeasance, and Compensation of Enforcers, 3 J. Leg. Studies 1 (1974).

24. For example, in 1911 the Supreme Court, in Dr. Miles Medical Co. v. John D. Parke \& Sons Co., 220 U.S. 373, held that the Sherman 
10.

24 continued

Act forbade resale price maintenance. Powerful pressures for exempting resale price maintenance from the Act eventuated in the passage of the Miller-Tydings Act of 1937 and the McGuire Act of 1952 which created such an exemption for states enacting Fair Trade laws. The enactment of the Miller-Tydings and McGuire Acts would have been unnecessary if the Court had responded to the rising political pressure for resale price maintenance by reinterpreting the Sherman Act to permit the practice. The Court's steadfastness in interpreting the Act in accordance with what it believed (correctly or not) to be the original understanding of the framers rather than the desires of the current legislators is a good, but not a rare, example of judicial independence.

Other examples from the trade-regulation field are the enactment of the original Clayton Act; the Robinson-Patman Amendments thereto; the 1938 Wheeler-Lea amendments to the Federal Trade Commission Act; the Celler-Kefauver Antimerger Act; and the Bank Merger Act of 1966. All resulted from congressional dissatisfaction with judicial interpretation of previously enacted statutes. Numerous examples from other federal statutory fields could also be cited.

25. See, for example, United States v. Butler, 297 U.S. 1 (1935); Schechter Corp. v. United States, 295 U.S. 495 (1935); Hopkins Savings Ass'n v. Cleary, 296 U.S. 315 (1935). 
26. For an alternative explanation, mainly relevant however to judicial review of administrative factfindings, see Richard A. Posner, An Economic Approach to Legal Procedure and Judicial Administration, 2 J. Leg. Studies 399, 416-17 (1973).

27. Some sense of the disproportion can be obtained by comparing the agency budgets listed in Geroge J. Stigler, The Process of Economic Regulation, 17 Antitrust Bu11. 207 (1972), with the estimates (admittedly rather crude) of the transfers involved in regulation presented in Richard A. Posner, The Social Costs of Monopoly and Regulation, 83 J. Po1. Econ. 807, 818 (1975).

28. In Part IID, infra.

29. An apparent counterexample is the just-compensation provision of the Fifth Amendment, which to be effective requires a substantial annnual appropriation by Congress to defray the expense of the government's eminent-domain proceedings.

30. See George J. Stigler, The Tenable Range of Functions of Local Government, in Staff of Jt. Econ. Comm., Federal Expenditure Policy for Economic Growth 213 (Jt. Comm. Print 1967). 
31. 01der judges have an additional advantage from the legislators' standpoint: their views are likely to be better known, and hence their behavior as judges is likely to be more predictable. On the other hand, older judges will be less susceptible to legislative or executive "bribery" in the form of promotion to higher office.

32. We do not, however, suggest that the protected groups are necessarily those urged by Charles $A$. Beard in his controversial book, An Economic Interpretation of the Constitution of the United States (1913). The details of Beard's analys is have been sharply criticized. See Robert E. Brown, Charles Beard and the Constitution (1956).

33. See Robert H. Bork, Neutral Principles and Some First Amendment Problems, 47 Ind. L. J. 1 (1971).

34. It may seem paradoxical to view as protectionist legislation that forbids regulation rather than limits entry. But whether a group will seek regulation or freedom from regulation depends on whether it anticipates friendly or unfriendly regulation. The "gun lobby" is another example of an interest group agressively seeking nonregulation.

35. Of course, as just mentioned, a group that feels vulnerable to legislative politics may on that account have a greater demand for constitutional protection. 
36. See note 3 supra; The Federalist, No. 10.

37. A view strongly implied in Gerald Gunther, The Supreme Court 1971 Term--Foreword: In Search of Evolving Doctrine on a Changing Court: A Model for a Newer Equal Protection, 86 Harv. L. Rev. 1, 20-21, 23 (1972), discussed critically in Richard A. Posner, The DeFunis Case and the Constitutionality of Preferential Treatment of Racial Minorities, 1974 Sup. Ct. Rev. 1, 29.

38. See text at note 4 supra.

39. See, for example, Gerald Gunther, supra note 3.

40. This is not to say that all legislation is inconsistent with efficiency or some other general welfare norm. Our point is rather that the judicial attitude implied by our analysis is one of indifference to the ethical content of the legislative or constitutional provisions that the court is being asked to enforce.

41. These deficiencies include the following: (1) Nullification fails to account for judicial interpretations of statutes that stop short of nullification but nevertheless significantly reduce the value of the legislative deals. Further, if lower-court 
41 continued

rulings gut the law in question, a Supreme court bent on nullification may accomplish this purpose simply by not granting certiorari. Thus, observed nullifications may be an alternative to unfavorable lower-court rulings, and present a biased picture of overall judicial unreliability. (2) If nullification of a particular law can be anticipated, legislators and groups are likely to be deterred from enacting that law in the first place, thęreby saving the costs of enactment. Observed nullifications, therefore, will fail to account for the number of laws that are not enacted because of anticipated nullification. (3) If nullification merely delays for a short period of time the passage of a similar law that is acceptable to the court (whose composition may change in the interval), the costs of observed nullifications may actually be less than the costs of continuous unfavorable interpretations that stop short of nullification.

42. See The Constitution of the U.S. of America, Analys is and Interpretation 1597-1619, at S125-S126. We have excluded one act from our enumeration, involving legal-tender clauses, that was declared unconstitutional in 1870 in $\mathrm{a}_{n}$ case overruled in 1871.

43. The one additional nullification during 1935-1936 was of a statute enacted in 1926. 
44. We emphasize that this inference is limited by the absence of data on unfavorable judicial interpretations of statutes which may be positively correlated with nullifications and vastly greater than the number of nullifications in any period.

45. Act of Feb. 9, 1909, \$2, 35 Stat. 614, as amended.

46. The frequency distribution of the time between passage and nullification for the 97 acts is as follows:

\begin{tabular}{cccccccc} 
& \multicolumn{7}{c}{ Time (years) } \\
\cline { 2 - 8 } & \multicolumn{1}{c}{4} & $5-8$ & $9-12$ & $13-16$ & $17-25$ & $26-50$ & $>50$ \\
\hline Number & 38 & 20 & 12 & 13 & 7 & 5 & 2 \\
\hline
\end{tabular}

47. See Table 1 supra.

48. Sixteen of the remaining 18 nullifictions in this period were of acts passed between 1946 and 1956, with an average lag between enactment and nullification of 15.7 years. The two other nullifications, which took place in 1970 and 1973, were of 1909 and 1960 acts respectively.

49. Since shorter tenure may have a positive effect on nullification of older laws (for example, laws that are more than eight years old at the time of nullification), the effect of TEN on all nullifications per term $\left(N_{t}\right)$ is uncertain. 
50. The period 1789-1972 spans the 1st-92nd Congresses. However, the first observation in equation 2.1 is the 5 th Congress (to allow for the passage of bills over the preceding eight years) and hence 2.1 contains 88 observations. Similary, in equation 2.2 the first observation is the 9th Congress, and the regression contains 84 observations. When all nullifications is the dependent variable, the BILL variable is computed for bills passed over the last 16 years, and thus the first observation in 2.3 is also the 9 th Congress.

51. Since there were only two nullifications during the first 38 Congresses, the narrower sample excludes at least 36 observations (depending on whether $N_{t}^{8}, N_{t}^{16}$, or $N_{t}$ is the dependent variable), where the dependent variable takes a zero value. The larger number of zero-valued dependent variables, particularly in the regressions that include the early Congresses, suggests that ordinary least squares is not the most appropriate statistical technique. We have not, however, made use of an alternative procedure (for example, tobit analysis).

52. An additional implication of the analys is is that the likelihood of nullification of older acts will decline with increase in tenure. This can be tested directly by employing $N_{t}-N_{t}^{8}$ as the dependent variable. The regression coefficients and $t$-values of TEN are .074 (2.237) for the 9th-92nd terms and .218 (2.556) for the 39th-92nd terms, which is contrary to our expectation. Note 
52 continued

that our definition of "older" acts (nine years or older) is arbitrary. Nevertheless, similar results are observed if 13 years is the cut-off point for older acts.

53. The regression coefficients and (t-values) of AGE and TEN when the other is excluded from equations 2.4-2.6 are as follows:

\begin{tabular}{ccc} 
& AGE & TEN \\
\hline $\mathrm{N}^{8}$ & .180 & .235 \\
& $(2.910)$ & $(2.527)$ \\
$\mathrm{N}^{16}$ & .234 & .398 \\
& $(3.263)$ & $(3.890)$ \\
$\mathrm{N}$ & .285 & .461 \\
& $(3.788$ & $(4.275)$
\end{tabular}

We observed that AGE was insignificant in equations 2.4-2.6 when TEN was also entered but here the $t$-value on AGE always exceeds 2.91 when TEN is excluded. TEN, which was insignificant in 2.4 when AGE was entered, is also highly significant in the above table. The effects of deleting either AGE or TEN in equations 2.1-2.3 are less dramatic because the correlation coefficient between the two variables drops to .41 on the full set of observations (1st-92nd Congressional terms). Nevertheless, TEN becomes significant in the $N^{16}$ and $N$ regressions when AGE is deleted. 
54. The following example illustrates how the data for each observation are constructed. During the term of the 57 th Congress (1901-1902) one act was nullified (1901). The act was 3 years old and there were 4 dissenting votes on the Court. Hence LAG equals 3 and DIS equals 4 . The values of AGE, TEN, PAR, and $N$ of this observation are their values at the end of the 57 th Congress. Note that if more than one act is nullified during a given Congressional term, then each of these acts is a separate observation in the regression. The LAG and DIS values would be act specific while the values assigned to the remaining variables, which are Congress specific, would be identical.

55. The $t$ and $N$ results, however, do not appear very robust. Ten acts were nullified during the term of the 74th Congress (19351936) and the average age of each act was 2.3 years. This compares to an average age of 10.8 years for the other 85 acts nullified. If we add a dummy variable to equation 2.7 (which takes the value 1 if the observation is from the 74 th Congress and 0 otherwise), then both $t$ and $N$ become insignificant though their signs are unchanged. 
Table 1

The Ratio of Multi-Period to Single-Period Returns

\begin{tabular}{|c|c|c|c|c|c|c|c|}
\hline \multirow[b]{3}{*}{$(1-p)$} & \multirow[b]{3}{*}{$\mathrm{T}$} & \multicolumn{6}{|c|}{ Interest Rates } \\
\hline & & \multicolumn{2}{|c|}{.10} & \multicolumn{2}{|c|}{.10} & \multicolumn{2}{|c|}{.20} \\
\hline & & $\infty$ & 10 & $\infty$ & 10 & $\infty$ & 10 \\
\hline .10 & & 9.5 & 5.7 & 5.0 & 4.3 & 3.6 & 3.4 \\
\hline .20 & 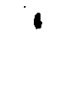 & 4.0 & 3.6 & 2.9 & 2.8 & 2.4 & 2.4 \\
\hline .30 & & 2.3 & 2.3 & 1.9 & 1.9 & 1.7 & 1.7 \\
\hline
\end{tabular}

$(1-p)=$ profitability of judicial nullification.

$T=$ number of time periods. 
Table 2

Federal Judicial Caseload--National Prohobition Act

\begin{tabular}{|c|c|c|c|c|}
\hline $\begin{array}{l}\text { Fiscal } \\
\text { Years } \\
\end{array}$ & $\begin{array}{r}\text { Prohibitio } \\
\text { Terminated } \\
\text { (Annual average) }\end{array}$ & $\begin{array}{l}\text { n Civil Cases } \\
\text { Per cent of total } \\
\text { Civil Terminations }\end{array}$ & $\begin{array}{l}\text { Prohibition } \mathrm{C} \\
\text { Terminated } \\
\text { (Annual average) }\end{array}$ & $\begin{array}{l}\text { riminal Cases } \\
\text { Per cent of total } \\
\text { Criminal Terminations }\end{array}$ \\
\hline 1920 & 92 & 1.6 & 5,095 & 14.8 \\
\hline 1921 & 622 & 9.8 & 21,297 & 45.0 \\
\hline 1922 & 1,537 & 18.8 & 28,743 & 54.1 \\
\hline 1923-1928 & 6,997 & 42.3 & 47,495 & 61.3 \\
\hline $1929-1933$ & 12,952 & 50.2 & 59,821 & 67.7 \\
\hline 1934 & 5,279 & 32.0 & 19,043 & 41.8 \\
\hline
\end{tabular}

Source: U.S. Att'y Gen'1, Annual Reports. 


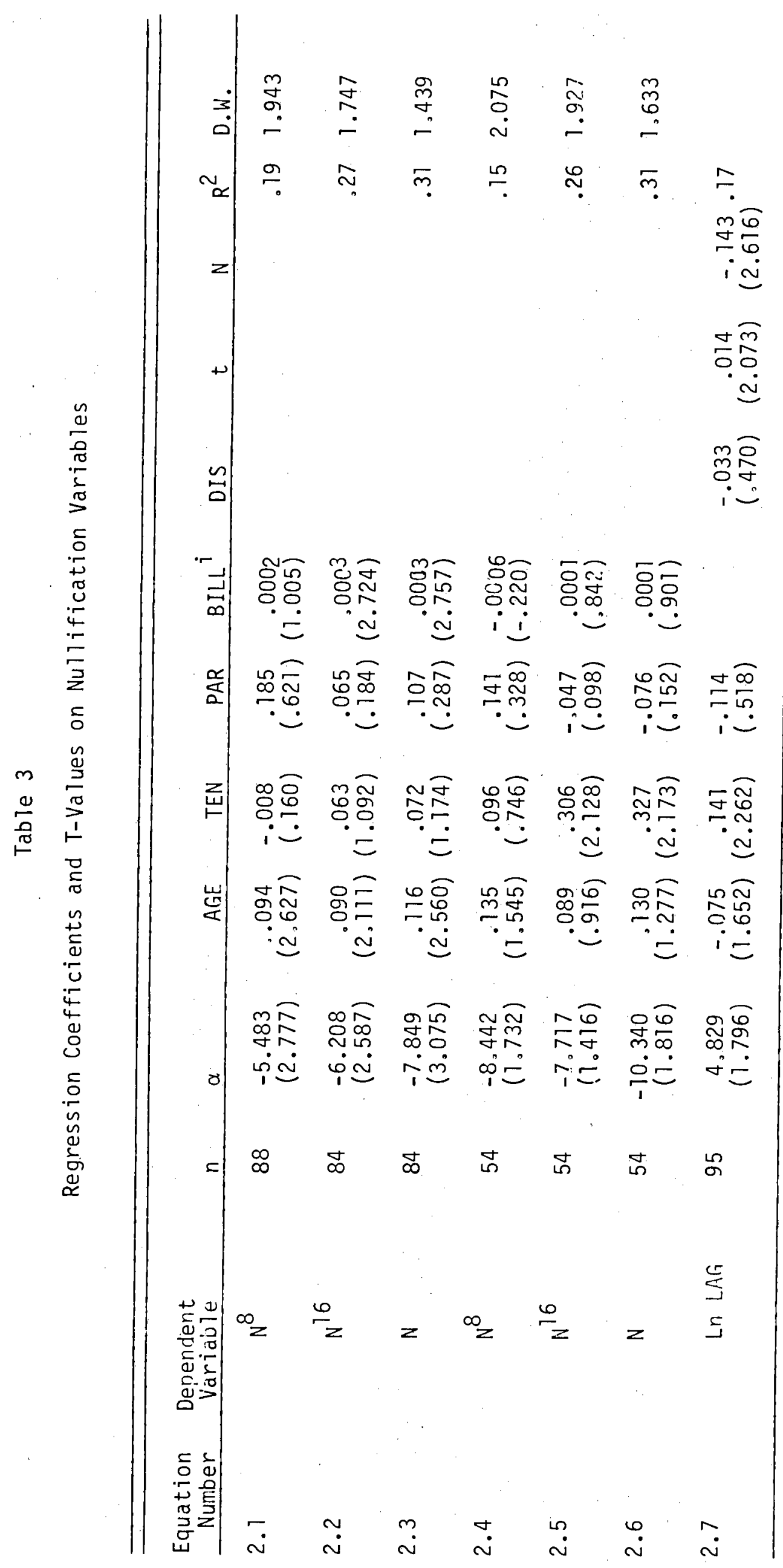

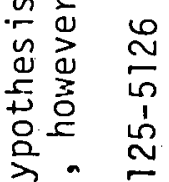

¿n in $\frac{N}{n}$

它点

음 둑

†宅

嵌

त东

일

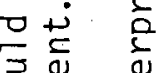

웛 首

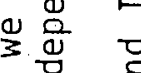

0 宅

ir n

$1 \geqslant$ is

$-\frac{\pi}{2}$

棺

స广

5.

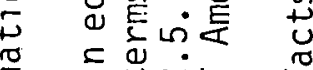

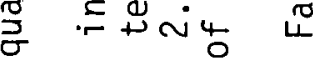

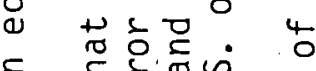

โ

क ब वे

ये

का टात

¿.

.

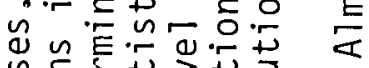

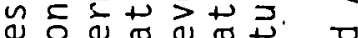

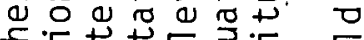

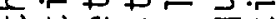

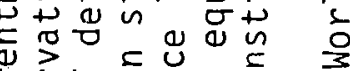

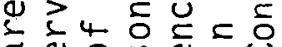

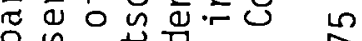

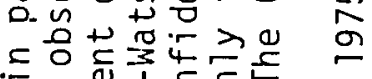

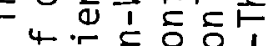

ه 0 讨

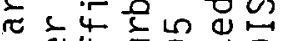

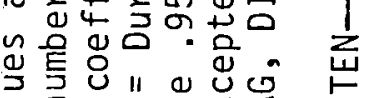

党 $=11$.

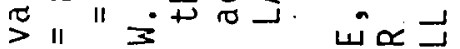
is 断

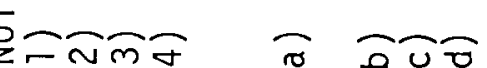

